\title{
Do pause ao play- Um novo modelo de aula
}

\section{Mairon Neves de Figueiredo ${ }^{1}$}

Já estamos em 2021 e o problema da pandemia de COVID 19 ainda assombra a educação pública no Brasil (BRASIL, 2020). Por todo o país se percebem severas limitações na implantação de políticas públicas voltadas a inserção do ensino remoto na grade escolar (PAZ, 2020). Quando bem implementado esse modelo de ensino é capaz de agregar diversos benefícios aos estudantes (FIGUEIREDO, 2020). As vídeos-aulas, se bem definidas e discutidas com conteúdos claros, ao serem disponibilizadas aos alunos apresentam potencial no estimulo do aprendizado. Do mesmo modo, as aulas remotas possibilitam que o material exposto apesar de breve possa ser interativo agregando aos vídeos vantagens únicas. Assim é de grande valia analisar o uso dessas ferramentas, já que mesmo durante o período pós-pandêmico seu legado pode vir a trazer grandes avanços ao ensino.

Neste modelo de ensino, desde que os estudantes tenham acesso a bons matérias, com exemplos e até exercícios, as aulas podem ser construídas em formatos simplificados e intuitivos, que ao serem revisados favoreçam uma melhor compreensão. Assim, temas de grande complexidade, que presencialmente necessitariam de horas de explicações e interações estudanteprofessor, podem ser assistidos novamente, auxiliando sua fixação (ROESLER; CERON; ANDRADE, 2003). Logo o estudo pós-aula, tende a ser melhor aproveitado, visto que as falas podem ser assistidas até que a interpretação atinja o a mensagem proposta, ou mesmo, que as dúvidas e questionamentos sejam melhor elaboradas para serem discutidas a posteriori. O distanciamento físico entre professor e aluno devido as limitações pode assim encontrar alternativas que não comprometam totalmente o aprendizado.

Os vídeos também possibilitam a que o aluno exerça o poder de pausar e continuar o estudo quando melhor lhe convém. Assim é possível que o estudante assista apenas trechos de uma aula, ou mesmo no horário e nos momentos em que o vídeo proporcione um conteúdo mais necessário.

Outro grande diferencial se refere a possibilidade de aceleração dos vídeos. Trechos longos e com falas espaçadas e lentas podem ter seu tempo de estudo comprimido sem que exista perda na compreensão. Com o tempo os estudantes são capazes de acelerar trechos e otimizar o aprendizado do conteúdo em um tempo hábil bem menor. 
Certamente as plataformas que utilizam vídeos aulas como ferramentas de estudos auxiliam na complementação do aprendizado (ALVES, 2011). Vale lembrar que desde o ensino fundamental, médio e superior (BRASIL, 2017) a realidade na dinâmica das aulas e o contato aluno-professor são bem diferentes. Entretanto o empasse em estimular a volta as aulas presenciais bate de frente com a necessidade do isolamento social (WHO, 2020), obrigando a adoção dos meios digitais de ensino. Assim sendo, este formato de ensino se mostra uma alternativa valida como ferramenta complementar na formação dos estudantes.

\section{REFERÊNCIAS}

ALVES, L. Educação a distância: conceitos e história no Brasil e no mundo. Revista Brasileira de Aprendizagem Aberta e a Distância, v. 10, n. 21, 2011.

BRASIL. DECRETO $\mathrm{N}^{\circ}$ 9.057, DE 25 DE MAIO DE 2017. Regulamenta o art. 80 da Lei $\mathbf{n}^{\circ}$ 9.394, de 20 de dezembro de 1996, que estabelece as diretrizes e bases da educação nacional. Brasília, DF, 2017. Disponível em: https://www.planalto.gov.br/ccivil_03/_ato20152018/2017/decreto/d9057.htm. Acesso em: 9 fev. 2021.

BRASIL. Portaria $n^{\circ}$ 343, de 17 de Março do Ministério da Educação.Dispõe sobre a substituição das aulas presenciais por aulas em meios digitais enquanto durar a situação de pandemia do Novo Coronavírus - COVID-19. Brasília, DF, 2020. Disponível em: http://www.in.gov.br/en/web/dou/-/portaria-n-343-de-17-de-marco-de-2020-248564376. Acesso em: 20 jan. 2020.

FIGUEIREDO, M. N. Como as aulas remotas podem trazer benefícios estudantis no enfretamento à pandemia de COVID? REVISTA PONTO DE VISTA, v. 9, n. 3, p. 143-145, 2020.

PAZ, I. Desafios do ensino remoto na pandemia - Revista Babel. Disponível em: http://www.usp.br/cje/babel/?p=168. Acesso em: 10 fev. 2021.

ROESLER, V., CERON, J. M., ANDRADE, M. Aulas remotas on-line utilizando transmissão de vídeo: estudo de caso na Informática na Unisinos. XIV Brazilian Symposium on Computers in Education. v. 1, n. 1, p.166-145, 2003.

WHO. Coronavirus disease (COVID-19) advice for the public. Disponível em: https://www.who.int/emergencies/diseases/novel-coronavirus-2019/advice-for-public. Acesso em: 19 dez. 2020. 